\title{
California Firewood Task Force’s message: "Buy it where you burn it"
}

T n 2006, the goldspotted oak borer (Agrilus auroguttatus, GSOB) was identified as the cause of increased oak die_off that had been occurring in San Diego County since at least 2002. Native to oak tree habitat in Mexico, Central America and Arizona, this invasive pest was likely brought to California on firewood imported from Arizona, traversing hundreds of miles of desert that normally would have provided a barrier to our forests.

GSOB's introduction into California is one of a growing list of insects and diseases found migrating into the United States and between states on firewood, often resulting in environmental and economic losses. Recognizing the clear risks associated with long-distance firewood movement as a potential vector for the spread of invasive species, a national movement is now under way, encouraging wood consumers to buy and burn wood locally.

"Working to coordinate messages among the various states involved in the firewood educational outreach campaign is the primary goal of the Firewood Outreach Coordinating Initiative (FOCI). Consistent key messages will help insure that the idea catches on and people embrace the 'Buy it where you burn it' motto,' said Leigh Greenwood of The Nature Conservancy and the Continental Dialogue on Non-Native Forest Insects and Diseases.

Firewood task force. With the establishment of the California Firewood Task Force, California officially joined the firewood effort in November 2010. Prior to its establishment, UC had implemented a GSOB education outreach campaign, which also addressed firewood issues as they related to the spread of GSOB. Tom Scott of UC Riverside and Kevin Turner of the California Department of Forestry

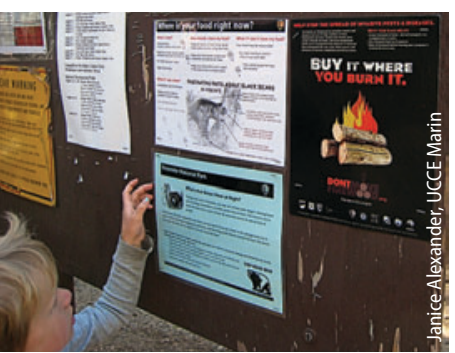

Educational posters were placed throughout Yosemite National Park, including at the Tuolomne Meadows campground. and Fire Protection (Cal Fire) led the effort to contact more than 100 local San Diego County firewood dealers, providing them with GSOB information and requesting their participation in voluntary best practices to limit the spread of pests through firewood.

Janice Alexander of UC Cooperative Extension in Marin County and Katie Palmieri of UC Berkeley developed a youth firewood outreach activity and piloted it at Marin County's Farm Day, where more than 500 youth and adults learned about how moving their camping firewood could unintentionally spread pests to their favorite parks. This activity was then reproduced in San

Diego with a specific GSOB focus and delivered to more than 3,000 youth and adults.

"The passport program was a super hit with the kids and parents," said Tracy Ellis of the San Diego County

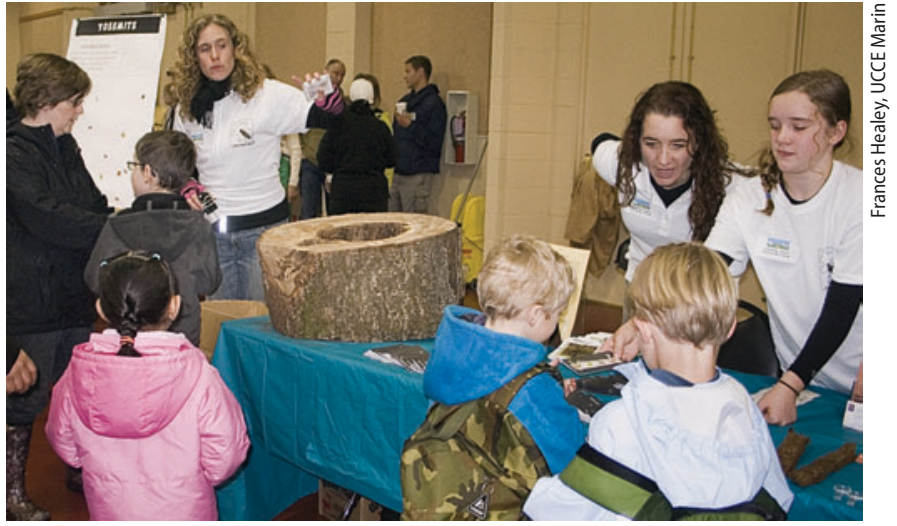

The concept of invasive forest pests moving on firewood was introduced at Marin County Farm Day in San Rafael, March 2011.

Department of Agriculture, Weights and Measures. "The kids really loved the participation, the passports, stamps and stickers. The parents could pick up a GSOB brochure along the way. Everyone gave the project a big thumbs up!"

Outreach and education. UC continues to provide leadership in GSOB and firewood outreach coordination as well as research and extension expertise, guiding public education efforts. Primary goals of the effort are to educate the public to "buy it where you burn it" and "don't move firewood" in an effort to keep GSOB, sudden oak death, pitch canker and other forest pests from spreading.

Key outreach activities to engage the public have included a campaign targeted at campers. Implemented during the summer 2011 camping season, the pilot campaign provided posters, Frisbees and playing cards for distribution in Yosemite National Park, Sequoia/Kings Canyon

National Park and San Diego County, and also trained campground hosts to deliver the firewood messages.

Brian Mattos of Yosemite National Park said, "We've already saturated our campgrounds with posters and will be handing out the playing cards to campers to help spread the word more directly to the public."

The effectiveness of the pilot outreach program will be evaluated with surveys, assessing camper knowledge of firewood and invasive species. The responses will be compared against earlier data to gauge whether attitudes and behaviors were changed by this initial campaign.

"In the next few months, we will be forming a long-term strategic plan for firewood outreach in California," said Don Owen of Cal Fire and task force chair. "These surveys and data will help our task force focus on the most effective tools and strategies for getting this important message out to the public." - Janice Alexander and Katie Palmieri 